\title{
Impact of Media on Academic Performance of College Students: A Case Study of Pakistani Government Colleges
}

\author{
Mahwish Rabia' $^{1}$, Huma Nawaz ${ }^{1}$, Naima Mubarak ${ }^{1}$, Sana Zulfiqar Ali² \\ ${ }^{1}$ Department of Statistics, Govt. College Women University, Sialkot, Pakistan \\ ${ }^{2}$ Department of Chemistry, Govt. Allama Iqbal College for Women, Sialkot, Pakistan \\ Email: mahwish.rabia@gcwus.edu.pk
}

How to cite this paper: Rabia, M., Nawaz, H., Mubarak, N. and Ali, S.Z. (2019) Impact of Media on Academic Performance of College Students: A Case Study of Pakistani Government Colleges. Open Journal of Social Sciences, 7, 429-442.

https://doi.org/10.4236/jss.2019.73036

Received: February 7, 2019

Accepted: March 23, 2019

Published: March 26, 2019

Copyright () 2019 by author(s) and Scientific Research Publishing Inc. This work is licensed under the Creative Commons Attribution International License (CC BY 4.0).

http://creativecommons.org/licenses/by/4.0/

\begin{abstract}
The aim of the study is to analyze the impact of media on the student's academic performance. The survey method using questionnaire is implemented for the data collection and analyzed using statistical package for social sciences (SPSS). The researcher distributed 270 surveys among the students of chosen colleges using stratified random sampling with equal allocation. Because the use of media is increasing day by day, there is an interest how it is influencing student's education. Different statistical techniques (descriptive and inferential), to find graphical charts and formulation of hypothesis are applied. It is found that $183(67 \%)$ respondents agreed that students waste much time on social media. Finally, it is recommended that students should be observed by parents and teachers when they use social networking sites.
\end{abstract}

\section{Keywords}

Media, Academic Performance, Students, Association, Study Habits

\section{Introduction}

Media, a collective communication outlet or tool, employed to store and deliver information or data, is influencing/changing the behavior of students, in terms of their academic performance. According to International Center for Media \& the Public Agenda (ICMPA), most college students are not just unwilling, but functionally unable to be, without their media links to the world.

Various researchers have examined the influence of media on users. Alwagait et al. [1] studied a relationship between the average number of hours that students spent of social media, a week and their Grade Point Average (GPA) scores. 
They found a non-linear relationship between the two factors and concluded that students' studies are negatively affected by the excessive use of social media. Yousuf [2] investigated the relationship between the usage of the Internet and academic achievement among the students of the English Department at Zarka University. The author found a change in the academic achievement of students, with less than 10 hours per week usage of social media, by more than $75 \%$ users. Lepp et al., [3] studied the relationship between cell phone use and GPA. They used regression analysis, which demonstrated that increased use of cell phone is associated with decreased academic performance of users. Ayub et al., [4] conducted a study to investigate the usage of Internet for academic and non-academic purposes, based on a survey on 1675 students, randomly selected from five different fields of study, which include social sciences, general sciences, engineering, agriculture and computer sciences. They observed that computer science students spend more time on the internet than others, and found that the total time spent on the Internet is weakly correlated with the time spent online, specifically for academic purposes. However, the social science students have a low but significant positive correlation between the overall time spent online and the time spent on the Internet for academic research, whereas the science students have a negative low correlation. The agriculture, engineering and computer sciences students have no correlation between Internet access duration and the use of the Internet for academic purposes. The findings show that students spare less time on the Internet, in regard for academic purpose. Lepp, Barkley and Karpinski [5] investigated the relationships between total cell phone use and texting, on Satisfaction with Life (SWL), in college students. They investigated that cell phone use/texting is negatively related to GPA and positively related to anxiety. They proved that GPA was positively related to SWL while anxiety was negatively related to SWL. Moreover, increased use of cell phone has a negative impact on academic performance, mental health, and subjective well-being or happiness of students. Yeboah and Ewur [6] studied that Whatsapp impacted negatively on the performance of tertiary students in Ghana. They investigated that Whatsapp takes much of students' study time, results in procrastination related problems, destroys students' spellings and grammatical construction of sentences, leads to lack of concentration during lectures, results in difficulty in balancing online activities (whatsapp) and academic preparation, and distracts students from completing their assignments and adhering to their private studies' time table. Hassan and Daniyal [7] analyzed that 69\% teenagers have more access in viewing television than any other medium. It has been revealed that $39 \%$ students are largely influenced by watching different television programs and music has particular influence than other contents. The study also depicts that $40 \%$ of the students spend two - three hours daily in watching television programs. Junco et al., [8] conducted an experimental study to determine the impact of using twitter on college students' engagement and grades. A total of 125 students participated in this study, where 70 lie in experimental group and 55 in control group. They used mixed effects analysis of variance (ANOVA) 
models to assess differences in engagement and grades. They also conducted content analyses of samples of Twitter exchanges. The findings of the study showed that the experimental group had a significantly greater increase in engagement than the control group. Their study provides enough experimental evidence that Twitter can be used as an educational tool to help engage students and to mobilize faculty. Jackson et al., [9] conducted a study to examine the antecedents and consequences of home Internet use on the academic performance of low-income students. Their findings indicate a positive impact on the grade of students with more use of internet. They also found that older children spend more time on the internet than the younger children, but age had no effect on the nature of the academic performance. Keith and Timothy [10] narrated that TV time had a smaller, negative effect on students' achievements, but homework had an important and positive impact. Parental involvement had direct effect on student's achievement scores and positively influenced the amount of time, the students spent on homework.

\section{Significance of the Study}

The significance of the study is:

1) To examine the negative and positive impacts of media on students.

2) To assess the effects of TV watching habit on student's academic performance.

3) To examine whether social media provide help to students in their studies.

4) To ascertain the relationship between media and student's learning experience.

5) To suggest measures to improve the study habits and usage of media by students.

\section{Hypothesis of the Study}

1). Is there any association between respondent's marks and their thinking that TV is changing their study habits?

2). Is there any association between respondent's marks and excessive use of internet?

3). Is there any association between respondent's marks and their TV watching habit?

4). Is there any association between respondent's marks and their interest, in spending their time on social media rather than spending on studies?

5). Is there any association between respondent's marks and excessive use of social network sites?

6). Are the respondents of two groups on the average have different thinking that some people's study is disturbed by friends, through social media and that, students are more interested in wasting their time on social media rather than spending on study?

7). Are the respondents of two groups on the average have different opinion on getting help through internet and on finding more information about their 
academic interest through media?

8). Are the respondents of two groups on the average have different opinion about their lower scores due to their too much TV watching habit and excessive use of internet, that is harmful for their studies?

9). Are the respondents of two groups on the average have different opinion about getting help through internet and social media, as an effective solution for the higher educational problem?

10). Are the respondents of two groups on the average have different opinion about getting help through internet and way of speaking, that is affected by media?

11). Are the respondents of two groups on the average have different opinion about their study time that is affected (negatively) by internet and aggressive behavior due to their TV watching habit?

12). Are the respondents on the average have different opinion on their aggressive behavior due to TV, excessive use of internet (harmful for studies) and speaking style, affected by media?

13). Are the respondents on the average have different opinion on their study time that is affected (negatively) by internet, TV and social media?

\section{Population and Sample}

\subsection{Population}

In this study population size of 10,000 is considered taking two colleges Govt. Allama Iqbal College for Women, Sialkot and Govt. Technical College for boys, Sialkot. There are 5000 female students in Govt. Allama Iqbal College for Women, Sialkot and 5000 male students in Govt. Technical College for boys, Sialkot.

\subsection{Sample}

The small representative part of the population is called sample. Using the formula provided by Yamane [11] a sample of size 270 is determined using Equation (1).

$$
n=\frac{N}{1+N \mathrm{e}^{2}}
$$

where " $N$ " is the population size and " $\mathrm{e}$ " is the margin of error.

\subsubsection{Sampling Technique}

Since there are two homogeneous groups one consisting of female students and the other consisting of male students. Therefore, stratified random sampling with equal allocation is used to select the samples from each stratum.

\subsubsection{Stratified Random Sampling with Equal Allocation}

The basic formula of stratified random sampling with equal allocation is described as

$$
n_{i}=\frac{n}{h} i=1,2,3 \cdots k
$$


where " $h$ " stands for number of strata. As there are two strata $(h=2)$ and sample size, $n=270$.

Therefore, $n_{i}=\frac{270}{2}=135$.

That is, 135 students are selected from Govt. Allama Iqbal College for Women, Sialkot and 135 male students from Govt. Technical College for boys, Sialkot.

\subsection{Testing of Hypothesis}

Hypothesis testing is a very important phrase of statistical inference. It is a procedure, which enables us to decide on the basis of information obtained from sample data whether to accept or reject a statement or an assumption about the value of parameter.

\subsection{Method Used for Analysis}

The collected data do not fulfill the normality assumption so non-parametric tests are used:

- Chi-square test.

- Mann Whitney U test (Alternative of " $t$ " test).

- Kruskal Wallis H test (Alternative of “One Way Anova” test).

\section{Results and Discussions}

The results given in Figure 1 show the demographic information related to the respondents and explains that out of 270 respondents, 50.5\% respondents are female and $50.5 \%$ respondents are male. It is also observed that out of 270 respondents, $46.3 \%$ respondents are $15-17$ years, $51.9 \%$ respondents are $18-20$ years and $1.9 \%$ respondents are above 20 years old. Also, according to area it can be seen that out of 270 respondents, $44.1 \%$ respondents belong to rural area and $55.9 \%$ respondents belongs to urban area. The respondents have different qualification levels i.e. out of 270 respondents, $51.5 \%$ respondents are from $1^{\text {st }}$ year, $17.0 \%$ respondents from $2^{\text {nd }}$ year, $25.9 \%$ respondents from $3^{\text {rd }}$ year and $5.6 \%$ respondents from $4^{\text {th }}$ year. The respondents are categorized into four levels according to their marks and it is clearly shown that $12.6 \%$ respondents achieve less than 50 percent marks, $31.1 \%$ respondents achieve 50 - 60 percent marks, $28.9 \%$ respondents achieve 61 - 71 percent marks and $27.4 \%$ respondents achieve above 71 percent marks. Also, the families of respondents have different income levels, it is observed that out of 270 respondents, $6.7 \%$ respondents have less than $15,000,35.6 \%$ respondents have $15,000-35,000,37.4 \%$ respondents have $36,000-56,000,7.0 \%$ respondents have $57,000-77,000$ and $13.3 \%$ respondents have above 77,000 income.

From Table 1 it can be seen that out of 270 respondents, $8.5 \%$ respondents are strongly disagree, $9.6 \%$ disagree, $10.4 \%$ neutral, $40.4 \%$ agree and $31.1 \%$ strongly agree on that they feel excessive use of internet is harmful for their studies. It can 
be seen that out of 270 respondents, $5.6 \%$ respondents are strongly disagree, $14.4 \%$ disagree, $19.6 \%$ neutral, $48.5 \%$ agree and $11.9 \%$ strongly agree on that they feel TV plays a very important role in the aggressive behavior of students. It can be seen that out of 270 respondents, $12.2 \%$ respondents are strongly disagree, $19.3 \%$ disagree, $15.9 \%$ neutral, $32.6 \%$ agree and $20.0 \%$ strongly agree on that they find more information regarding their academic interest and career through media. It can be seen that out of 270 respondents, $11.1 \%$ respondents are strongly disagree, $9.6 \%$ disagree, $11.5 \%$ neutral, $24.8 \%$ agree and $43.0 \%$ strongly agree on that they feel students are more interested in wasting their time on social media rather than spending on studies. It can be seen that out of 270 respondents, $11.1 \%$ respondents are strongly disagree, $14.8 \%$ disagree, $16.3 \%$ neutral, $36.3 \%$ agree and $21.5 \%$ strongly agree on that they feel media is affecting their way of speaking in everyday life. It can be seen that out of 270 respondents, $24.1 \%$ respondents are strongly disagree, $11.1 \%$ disagree, $10.0 \%$ neutral, $33.0 \%$ agree and $21.9 \%$ strongly agree on that they think students watch too much TV have lower scores in exams.

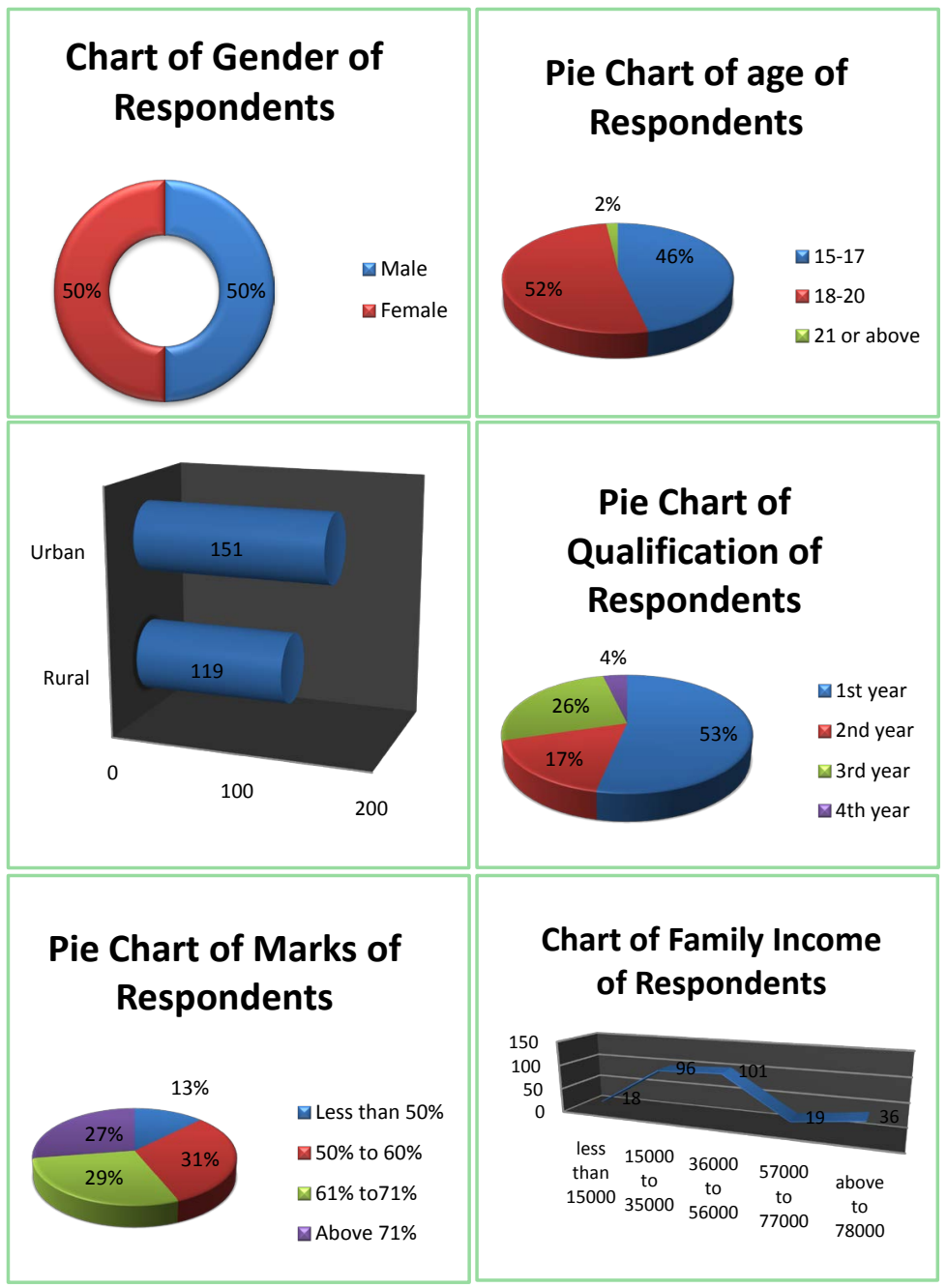

Figure 1. Graphical representation of demographic factors. 
Table 1. Frequency distribution and percentage (in parenthesis) of the respondents.

\begin{tabular}{ccccccc}
\hline & S.D & D & N & A & S.A & Total \\
\hline $\begin{array}{c}\text { Effect of Internet on study time } \\
\text { Role of TV in the aggressive } \\
\text { behavior of Students }\end{array}$ & $23(8.5)$ & $26(9.6)$ & $28(10.4)$ & $109(40.4)$ & $84(31.1)$ & 270 \\
$\begin{array}{c}\text { Students get more information } \\
\text { regarding academic interest and } \\
\text { career through media. } \\
\quad \text { Students wasting }\end{array}$ & $33(12.2)$ & $52(19.3)$ & $43(15.9)$ & $88(32.6)$ & $54(20.0)$ & 270 \\
$\begin{array}{c}\text { time on Social Media } \\
\text { Effect of media in way of speaking } \\
\text { in everyday life. }\end{array}$ & $30(11.1)$ & $26(19.6)$ & $31(11.5)$ & $67(24.8)$ & $116(43.0)$ & 270 \\
$\begin{array}{c}\text { Students who watch too much TV } \\
\text { have lower scores in exams. }\end{array}$ & $65(24.1)$ & $30(11.1)$ & $27(10.0)$ & $89(33.0)$ & $59(21.9)$ & 270 \\
\hline
\end{tabular}

\subsection{Chi-Square Test}

$\chi^{2}$-test is frequently used to check the association between two attributes for data analysis. In this paper we use this test to check the association between different attributes and the results are summarized in Tables 2-6.

\subsubsection{Hypothesis \# 1}

$\mathrm{H}_{0}$ : There is no association between respondent's marks and thinking that TV is changing their study habits.

$\mathrm{H}_{1}$ : There is association between respondent's marks and thinking that TV is changing their study habits.

In Table $2, x^{2}=22.998, \mathrm{p}=0.028$ which is significant at 0.05 level of significance and falls in critical region, so reject our null hypothesis and conclude that there is association between respondent's marks and their thinking that TV is changing their study habits.

\subsubsection{Hypothesis \# 2}

$\mathrm{H}_{0}$ : There is no association between respondent's marks and excessive use of internet (harmful for their studies).

$\mathrm{H}_{1}$ : There is association between respondent's marks and excessive use of internet (harmful for their studies).

In Table 3, since $\mathrm{p}=0.048$ which is less than 0.05 and falls in critical region, so reject our null hypothesis and conclude that there is association between respondent's marks and excessive use of internet (harmful for their studies).

\subsubsection{Hypothesis \# 3}

$\mathrm{H}_{0}$ : There is no association between respondent's marks and their TV watching habit (that results in their lower scores in exams).

$\mathrm{H}_{1}$ : There is association between respondent's marks and their TV watching habit (that results in their lower scores in exams).

In Table 4 , since $\mathrm{p}=0.000$ which is less than 0.05 and falls in critical region, so reject our null hypothesis and conclude that there is association between respondent's marks and their TV watching habit that results in their lower scores in exams. 
Table 2. Association between respondent's marks and their thinking that TV is changing their study habits.

\begin{tabular}{|c|c|c|c|c|c|c|}
\hline \multicolumn{7}{|c|}{ I feel that TV is changing my study habits. } \\
\hline Marks & S.D & $\mathrm{D}$ & $\mathbf{N}$ & A & S.A & Total \\
\hline Less than $50 \%$ & 10 & 5 & 5 & 8 & 6 & 34 \\
\hline $50 \%$ to $60 \%$ & 8 & 10 & 13 & 40 & 13 & 84 \\
\hline $61 \%$ to $71 \%$ & 5 & 11 & 18 & 24 & 20 & 78 \\
\hline Above $71 \%$ & 7 & 11 & 15 & 31 & 10 & 74 \\
\hline Total & 30 & 37 & 51 & 103 & 49 & 270 \\
\hline \multicolumn{3}{|c|}{$x^{2}=22.998$} & \multicolumn{4}{|c|}{$P$-value $=0.028^{*}($ Significant $)$} \\
\hline
\end{tabular}

Table 3. Association between respondent's marks and excessive use of internet.

\begin{tabular}{ccccccc}
\hline & \multicolumn{5}{c}{ I feel that excessive use of internet is harmful for my studies } \\
\hline Marks & S.D & D & N & A & S.A & Total \\
\hline Less than $50 \%$ & 5 & 5 & 5 & 7 & 12 & $\mathbf{3 4}$ \\
$50 \%$ to $60 \%$ & 5 & 8 & 5 & 36 & 30 & $\mathbf{8 4}$ \\
$61 \%$ to $71 \%$ & 9 & 15 & 5 & 25 & 24 & $\mathbf{7 8}$ \\
Above $71 \%$ & 5 & 5 & 13 & 31 & 20 & $\mathbf{7 4}$ \\
Total & $\mathbf{2 4}$ & $\mathbf{3 3}$ & $\mathbf{2 8}$ & $\mathbf{9 9}$ & $\mathbf{8 6}$ & $\mathbf{2 7 0}$ \\
$\boldsymbol{x}^{2}=21.161$ & & \multicolumn{5}{c}{-value $=0.048^{*}$ (Significant) } \\
\hline
\end{tabular}

Table 4. Association between respondent's marks and thinking that students who watch too much TV have lower scores in exams.

\begin{tabular}{ccccccc}
\hline & \multicolumn{5}{c}{ I think students watch too much TV have lower scores in exams. } \\
\hline Marks & S.D & D & N & A & S.A & Total \\
\hline Less than $50 \%$ & 5 & 5 & 7 & 9 & 8 & $\mathbf{3 4}$ \\
$50 \%$ to $60 \%$ & 7 & 12 & 10 & 40 & 15 & $\mathbf{8 4}$ \\
61\% to 71\% & 11 & 8 & 5 & 32 & 22 & $\mathbf{7 8}$ \\
Above 71\% & 44 & 5 & 5 & 6 & 14 & $\mathbf{7 4}$ \\
Total & $\mathbf{6 7}$ & $\mathbf{3 0}$ & $\mathbf{2 7}$ & $\mathbf{8 7}$ & $\mathbf{5 9}$ & $\mathbf{2 7 0}$ \\
$\boldsymbol{x}^{2}=\mathbf{8 2 . 5 1 5}$ & & & $P$-value & $=0.000^{*}$ (Significant) &
\end{tabular}

Table 5. Association between respondent's marks and their interest, in spending their time on social media.

I feel that students are more interested in wasting their time on social media rather than spending on studies.

\begin{tabular}{ccccccc}
\hline Marks & S.D & D & N & A & S.A & Total \\
\hline Less than $50 \%$ & 6 & 5 & 5 & 8 & 10 & 34 \\
$50 \%$ to $60 \%$ & 9 & 6 & 7 & 25 & 37 & $\mathbf{8 4}$ \\
61\% to 71\% & 10 & 6 & 5 & 12 & 45 & $\mathbf{7 8}$ \\
Above 71\% & 5 & 9 & 14 & 22 & 22 & $\mathbf{7 4}$ \\
Total & 30 & $\mathbf{2 6}$ & $\mathbf{3 1}$ & $\mathbf{6 7}$ & $\mathbf{1 1 6}$ & $\mathbf{2 7 0}$ \\
$\boldsymbol{x}^{2}=\mathbf{2 3 . 0 7 0}$ & & & $P$-value $=0.027^{*}$ (Significant) & \\
\hline
\end{tabular}


Table 6. Association between respondent's marks and excessive use of social network sites.

\begin{tabular}{ccccccc}
\hline & \multicolumn{5}{c}{ I feel excessive use of social network site } \\
& may badly effect the academic life and learning experiences of student \\
\hline Marks & S.D & D & N & A & S.A & Total \\
\hline Less than $50 \%$ & 6 & 5 & 5 & 13 & 5 & 34 \\
$50 \%$ to $60 \%$ & 6 & 5 & 10 & 45 & 18 & $\mathbf{8 4}$ \\
$61 \%$ to $71 \%$ & 6 & 5 & 19 & 29 & 19 & $\mathbf{7 8}$ \\
Above 71\% & 8 & 17 & 6 & 23 & 20 & $\mathbf{7 4}$ \\
Total & $\mathbf{2 6}$ & $\mathbf{3 2}$ & $\mathbf{4 0}$ & $\mathbf{1 1 0}$ & $\mathbf{6 2}$ & $\mathbf{2 7 0}$ \\
$\boldsymbol{x}^{2}=\mathbf{3 0 . 1 9 3}$ & & & $P$-value & $=0.003^{*}$ (Significant) & \\
\hline
\end{tabular}

\subsubsection{Hypothesis \# 4}

$\mathrm{H}_{0}$ : There is no association between respondent's marks and their interest, in spending their time on social media rather than spending on studies.

$\mathrm{H}_{1}$ : There is association between respondent's marks and their interest, in spending their time on social media rather than spending on studies.

In Table 5, Since $\mathrm{p}=0.027$ which is less than 0.050 and falls in critical region, so reject our null hypothesis and conclude that there is association between respondent's marks and their interest, in spending their time on social media rather than spending on studies.

\subsubsection{Hypothesis \# 5}

$\mathrm{H}_{0}$ : There is no association between respondent's marks and excessive use of social network sites (which may badly affect the academic life and learning experience of students).

$\mathrm{H}_{1}$ : There is association between respondent's marks and excessive use of social network sites (which may badly affect the academic life and learning experience of students).

In Table 6, Since $p=0.003$ which is less than 0.050 and falls in critical region, so reject our null hypothesis and conclude that there is association between respondent's marks and excessive use of social network sites, which badly affect the academic life and learning experience of students.

\subsection{Mann Whitney U Test (Alternative of " $t$ " Test)}

\subsubsection{Hypothesis \# 6}

$\mathrm{H}_{0}$ : Respondents of two groups on the average have same thinking that some people's study is disturbed by friends, through social media and that, students are more interested in wasting their time on social media rather than spending on study.

$\mathrm{H}_{1}$ : Respondents of two groups on the average have different thinking that some people's study is disturbed by friends, through social media and that, students are more interested in wasting their time on social media rather than spending on study. 


\subsubsection{Hypothesis \# 7}

$\mathrm{H}_{0}$ : Respondents of two groups on the average have same opinion on getting help through internet and on finding more information about their academic interest through media.

$\mathrm{H}_{1}$ : Respondents of two groups on the average have different opinion on getting help through internet and on finding more information about their academic interest through media.

\subsubsection{Hypothesis \# 8}

$\mathrm{H}_{0}$ : Respondents of two groups on the average have same opinion about their lower scores due to their too much TV watching habit and excessive use of internet that is harmful for their studies.

$\mathrm{H}_{1}$ : Respondents of two groups on the average have different opinion about their lower scores due to their too much TV watching habit and excessive use of internet that is harmful for their studies.

\subsubsection{Hypothesis \# 9}

$\mathrm{H}_{0}$ : Respondents of two groups on the average have same opinion about getting help through internet and social media, as an effective solution for the higher educational problem.

$\mathrm{H}_{1}$ : Respondents of two groups on the average have different opinion about getting help through internet and social media, as an effective solution for the higher educational problem.

\subsubsection{Hypothesis \# 10}

$\mathrm{H}_{0}$ : Respondents of two groups on the average have same opinion about getting help through internet and way of speaking that is affected by media.

$\mathrm{H}_{1}$ : Respondents of two groups on the average have different opinion about getting help through internet and way of speaking that is affected by media.

\subsubsection{Hypothesis \# 11}

$\mathrm{H}_{0}$ : Respondents of two groups on the average have same opinion about their study time that is affected (negatively) by internet and aggressive behavior due to their TV watching habit.

$\mathrm{H}_{1}$ : Respondents of two groups on the average have different opinion about their study time that is affected (negatively) by internet and aggressive behavior due to their TV watching habit.

It is clear from Table 7 that in hypothesis \# 6, $\mathrm{p}=0.000$ which is less than 0.05 and falls in critical region so null hypothesis is rejected and concluded that respondents of two groups on the average have different thinking that some people's study is disturbed by friends through social media and that, students are more interested in wasting their time on social media rather than spending on study. In hypothesis \# 7 as $\mathrm{p}=0.002$ which is less than 0.05 , we reject our null hypothesis and conclude that respondents of two groups on the average have different opinion on getting help through internet and on finding more information about their academic interest through media. From hypothesis \# 8 it is 
Table 7. (a) Mann Whitney U Test; (b) Kruskal Wallis H test.

(a)

\begin{tabular}{lccll}
\hline & $\mathrm{U}$ & Z-Statistic & P value & Conclusion \\
\hline Hypothesis \# 6 & 29438.000 & -4.084 & $0.000^{*}$ & Significant \\
Hypothesis \# 7 & 30953.00 & -3.149 & $0.002^{*}$ & Significant \\
Hypothesis \# 8 & 28605.000 & -4.503 & $0.000^{*}$ & Significant \\
Hypothesis \# 9 & 29275.500 & -4.101 & $0.000^{*}$ & Significant \\
Hypothesis \# 10 & 29092.500 & -4.229 & $0.000^{*}$ & Significant \\
Hypothesis \# 11 & 30480.000 & -3.443 & $0.001^{*}$ & Significant \\
\hline
\end{tabular}

(b)

\begin{tabular}{lcll}
\hline & $\mathrm{H}$ & P value & Conclusion \\
\hline Hypothesis \# 12 & 13.163 & $0.001^{*}$ & Significant \\
Hypothesis \# 13 & 21.032 & $0.000^{*}$ & Significant \\
\hline
\end{tabular}

concluded that as $\mathrm{p}=0.000$ which is less than 0.05 so, we reject our null hypothesis and conclude that respondents of two groups on the average have different opinion about their lower scores due to their too much TV watching habit and about their excessive use of internet, that is harmful for their studies. In hypothesis \# 9 as $\mathrm{p}=0.000$ which is less than 0.05 so we reject our null hypothesis and conclude that respondents of two groups on the average have different opinion about getting help through internet and about social media, as an effective solution for the higher educational problem. In hypothesis \# 10 as $p=0.000$ which is less than 0.05 so we reject our null hypothesis and conclude that respondents of two groups on the average have different opinion about getting help through internet and about their way of speaking, that is affected by media. Similarly, in hypothesis \# 11 as $\mathrm{p}=0.001$ which is less than 0.05 so we reject our null hypothesis and conclude that respondents of two groups on the average have different opinion about their study time that is affected (negatively) by internet and aggressive behavior due to their TV watching habit.

\subsection{Kruskal Wallis H Test}

\subsubsection{Hypothesis \# 12}

$\mathrm{H}_{0}$ : Respondents on the average have same opinion on their aggressive behavior due to TV, excessive use of internet (harmful for studies) and their speaking style, affected by media.

$\mathrm{H}_{1}$ : Respondents on the average have different opinion on their aggressive behavior due to TV, excessive use of internet (harmful for studies) and their speaking style, affected by media.

\subsubsection{Hypothesis \# 13}

$\mathrm{H}_{0}$ : Respondents on the average have same opinion on their study time that is affected (negatively) by internet, TV and social media. 
$\mathrm{H}_{1}$ : Respondents on the average have different opinion on their study time that is affected (negatively) by internet, TV and social media.

In Hypothesis \# 12, p $=0.001$ which is less than 0.05 , we reject our null hypothesis and conclude that respondents on the average have different opinion on their aggressive behavior due to TV, excessive use of internet (harmful for studies) and their speaking style, affected by media. It is also clear from Hypothesis \# 13 that $\mathrm{p}=0.000$ which is less than 0.05 so we reject our null hypothesis and conclude that respondents of two groups on the average have different opinion on their study time that is affected(negatively) by internet, TV and social media.

\section{Conclusion}

The most important things in a student's life are to become a person with moral character by studying, learning good habits and gaining knowledge. The excessive use of social networking sites not only destroys student's future but also produces stress, anxiety or fear which leads to depression. The purpose of this paper is to examine the impact (role) of media on student's life and their academic performance. The association between variables is found using chi square test and on average opinions are found using Mann Whitney $u$ test and Kruskal Wallis $\mathrm{H}$ test. Media tells about the latest technology and information that helps a student to go far and far in his life. But on the other hand, like everything, the misuse of media can bring a student back, on the road of success in his life. In this study we have observed that students are aware from social network sites and have access to them. Although there are many advantages of media but at the same time, social media is negatively influencing the students' academic performance because they spend much time on chatting through internet, watching TV, mobile phones and their academic activities are neglected and left to suffer. Many ethics, regulations and policies on use of social media sites should be imposed by the government on colleges and academic institutions.

\section{Suggestions}

Carefully noticing students by teachers and parents is essential. They should be monitored when watching social media sites through computers, tablets or mobile phones in class. Some policies and regulations should be set by the management authorities of colleges and some vulgar websites should be restricted, moreover, guiding students about safety measures of social networking sites, and if assigning homework that requires using the internet, preparing a list of websites that are safe to use and making these available to parents. This will create a balance between social media and academic activities of students to avoid obstacles in the academic performance of the students.

\section{Future Study}

The research topic can studied in the future by considering either government has set some ethics and regulations on use of vulgar social media sites or not and 
how effectively these policies are implemented to save students' future.

\section{Conflicts of Interest}

The authors declare no conflicts of interest regarding the publication of this paper.

\section{References}

[1] Alwagait, E., Shahzad, B. and Alim, S. (2015) Impact of Social Media Usage on Students Academic Performance in Saudi Arabia. Computers in Human Behavior, 51, 1092-1097. https://doi.org/10.1016/j.chb.2014.09.028

[2] Yousuf, A. (2015) The Relationship between Use of the Internet and Academic Achievement among Students of the Department of English Language in Zarqa University. Zarqa Journal for Research and Studies in Humanities, 341, 1-14.

[3] Lepp, A., Barkley, J.E. and Karpinski, A.C. (2014) The Relationship between Cell Phone Use and Academic Performance in a Sample of US College Students. Sage Open, 5, 343-350. https://doi.org/10.1177/2158244015573169

[4] Ayub, A.F.M., Hamid, W.H.W. and Nawawi, M.H. (2014) Use of Internet for Academic Purposes among Students in Malaysian Institutions of Higher Education. Turkish Online Journal of Educational Technology-TOJET, 31, 232-241. https://doi.org/10.1016/j.chb.2013.10.049

[5] Lepp, A., Barkley, J.E. and Karpinski, A.C. (2014) The Relationship between Cell Phone Use, Academic Performance, Anxiety, and Satisfaction with Life in College Students. Computers in Human Behavior, 31, 343-350.

[6] Yeboah, J. and Ewur, G.D. (2014) The Impact of WhatsApp Messenger Usage on Students Performance in Tertiary Institutions in Ghana. Journal of Education and Practice, 5, 157-164.

[7] Hassan, A. and Daniyal, M. (2013) Cartoon Network and Its Impact on Behavior of School Going Children: A Case Study of Bahawalpur, Pakistan.

[8] Junco, R., Heiberger, G. and Loken, E. (2011) The Effect of Twitter on College Student Engagement and Grades. Journal of Computer Assisted Learning, 27, 119-132. https://doi.org/10.1111/j.1365-2729.2010.00387.x

[9] Jackson, L.A., Von Eye, A., Biocca, F.A., Barbatsis, G., Zhao, Y. and Fitzgerald, H.E. (2006) Does Home Internet Use Influence the Academic Performance of Low-Income Children? Developmental Psychology, 42, 429-435. https://doi.org/10.1037/0012-1649.42.3.429

[10] Keith, T.Z., Reimers, T.M., Fehrmann, P.G., Pottebaum, S.M. and Aubey, L.W. (1986) Parental Involvement, Homework, and TV Time: Direct and Indirect Effects on High School Achievement. Journal of Educational Psychology, 78, 373-380. https://doi.org/10.1037/0022-0663.78.5.373

[11] Yamane, T. (1967) Statistics: An Introductory Analysis. Harper and Row, New York. 
Questionnaire on impact of media on Academic Performance of Students

Gender ... Age ... years. Area Rural/Urban Qualification. $1^{\text {st }}$ year $/ 2^{\text {nd }}$ year $/ 3^{\text {rd }}$ year $/ 4^{\text {th }}$ Year Marks in previous examination ... Family Monthly Income ... rupees. My Monthly Expenditure ... rupees.

1) $\mathrm{S} . \mathrm{A}=$ Strongly Agree 2) $\mathrm{A}=$ Agree 3) $\mathrm{N}=$ Neutral 4) $\mathrm{D}=$ Disagree 5) S.D = Strongly Disagree.

1 I feel that internet affect my study time negatively.

I think students who watch too much TV have lower scores in exams.

I feel that TV plays a very important role in the aggressive behavior of students.

4 I use internet through my mobile phone.

5 I feel that excessive use of internet is harmful for my studies.

6 I feel that TV is changing my study habits.

7 Internet helps me in my study.

eel that some young people's study is disturbed when friends join them through social media.

I feel social media is an effective and efficient solution for the higher educational problem.

10

I feel excessive use of social network site may badly effect the academic life and learning experiences of the student

I find more information regarding my academic interest and career through media.

12 I think media is affecting my way of speaking in everyday life.

I feel that students are more interested in wasting their time on social media rather than spending on study.

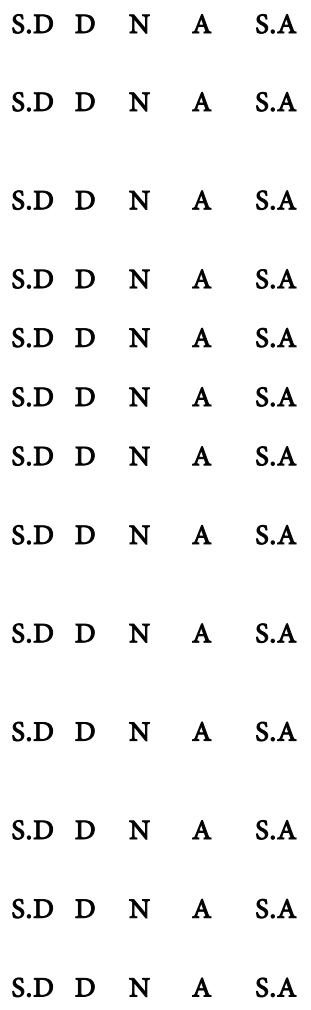

